\title{
Uptake of dissolved inorganic nitrogen, urea and amino acids in the Scheldt estuary: comparison of organic carbon and nitrogen uptake
}

\author{
Maria G. I. Andersson*, Pieter van Rijswijk, Jack J. Middelburg \\ Netherlands Institute of Ecology (NIOO-KNAW), Centre for Estuarine and Marine Ecology, PO Box 140, 4400 AC Yerseke, \\ The Netherlands
}

\begin{abstract}
Uptake of dissolved ammonium, nitrate, nitrite, urea and amino acids was studied in the Scheldt estuary in different seasons over a salinity gradient. The importance of inorganic nitrogen sources was compared to that of urea and amino acids and the relative use of urea and amino acid nitrogen and carbon was studied. Urea and amino acids constituted up to 43 and $29 \%$ of total nitrogen uptake, respectively, and were of similar importance as inorganic substrates. Ammonium oxidation by nitrifiers and ammonium uptake by algae and bacteria were of similar magnitude. In January, April and November, amino acids constituted a source of both nitrogen and carbon while urea mainly constituted a source of carbon. During the summer months, amino acids were used mainly as a source for nitrogen, while urea was a source for both carbon and nitrogen; urea was rarely used as nitrogen substrate alone. Due to this seasonal uncoupling of nitrogen and carbon assimilation, dually labeled substrates are necessary to assess the importance of urea and amino acids as substrates for organic nitrogen and carbon.
\end{abstract}

KEY WORDS: Uptake $\cdot$ Nitrogen $\cdot$ Carbon $\cdot$ Inorganic $\cdot$ Organic $\cdot$ DON $\cdot$ Nitrification

Resale or republication not permitted without written consent of the publisher

\section{INTRODUCTION}

All organisms need nitrogen, and both dissolved inorganic and organic nitrogen (DIN and DON) can be used as substrates by micro-organisms. Measurements of DIN uptake are straightforward using ${ }^{15} \mathrm{~N}$ labeled ammonium $\left(\mathrm{NH}_{4}{ }^{+}\right)$, nitrate $\left(\mathrm{NO}_{3}{ }^{-}\right)$and nitrite $\left(\mathrm{NO}_{2}{ }^{-}\right)$and a large body of data exists (e.g. Dugdale \& Goering 1967, McCarthy et al. 1977, Middelburg \& Nieuwenhuize 2000a, Tobias et al. 2003). Uptake of DON is difficult to quantify since it contains a large number of compounds, such as proteins, oligopeptides, purines, nucleic acids, and humic substances, and the exact composition of the pool is unknown. As a consequence, application of ${ }^{15} \mathrm{~N}$ labeled substrates is cumbersome and few data exist (Bronk 2002). To increase our understanding of nitrogen $(\mathrm{N})$ cycling in aquatic systems it is important to quantify the importance of DIN and DON uptake at the same time. Nitrification, oxidation of $\mathrm{NH}_{4}{ }^{+}$to $\mathrm{NO}_{3}{ }^{-}$, is another key process in estuarine nitrogen cycling but parallel studies of other processes consuming or producing $\mathrm{NH}_{4}{ }^{+}$and $\mathrm{NO}_{3}{ }^{-}$are rare.

Many studies have shown DON to be an important $\mathrm{N}$ source for phytoplankton (Palenik \& Morel 1990, Bronk \& Glibert 1993, Berman \& Chava 1999, Fan \& Glibert 2005) as well as for heterotrophic bacteria (Wheeler \& Kirchman 1986, Hoch \& Kirchman 1995, Middelboe et al. 1995, Rosenstock \& Simon 2001). The majority of these studies either measured uptake of total DON in laboratory cultures or quantified the uptake of well-defined substrates (e.g. amino acids) in batch cultures or in natural samples. Some microorganisms can use DON-derived N directly (Berg et al. 1997, Mulholland et al. 2002) while others use DON indirectly, i.e. by using extracellular enzymes to mobilize N from DON (Palenik \& Morel 1990, Berg et al. 2002, Mulholland et al. 2003). $\mathrm{NH}_{4}{ }^{+}$can also be released from DON through inorganic reactions, such 
as photochemical oxidation (Bushaw et al. 1996). It is not clear whether $\mathrm{N}$-containing dissolved organic compounds are used as substrates exclusively for $\mathrm{N}$, for carbon (C), or for both. Previous studies addressing this question on natural samples are few. Petersen et al. (2004) showed that both heterotrophic and nitrifying bacteria can incorporate a small amount of $\mathrm{C}$ from urea. Jørgensen (2006) reported urea uptake by estuarine bacteria and concluded that uptake is variable and rather unpredictable. For phytoplankton, the results are variable and sometimes conflicting (Mulholland et al. 2002, 2003, 2004, Fan \& Glibert 2005). Fan \& Glibert (2005) found urea to be a C substrate during a dinoflagellate bloom, while Mulholland et al. (2004) concluded that urea was not used as a substrate for $\mathrm{C}$ during a phytoplankton bloom. Mulholland et al. (2003) reported uncoupled uptake of amino acid, i.e. N was taken up preferentially to $\mathrm{C}$ along an estuarine gradient. This contradicted their previous findings regarding uptake in the phytoplankton Aureococcus anophagefferens, whereby both $\mathrm{C}$ and $\mathrm{N}$ were incorporated from amino acids (Mulholland et al. 2002). Clearly, more observations are required to identify the differential assimilation of $\mathrm{C}$ and $\mathrm{N}$ by natural communities.

Another key question is to what extent dissolved organic matter (DOM) contributes to $\mathrm{N}$ uptake by bacteria and phytoplankton compared to dissolved inorganic nutrients, since there are few data on this. In a recent review, Berman \& Bronk (2003) stated that there is still a need for greater appreciation and understanding of the potential role of DON in aquatic systems. Estuaries receive DIN and DON via riverine input, direct land runoff, atmosphere inputs and from the sea. Moreover, during transport through an estuary to the sea, these compounds undergo many transformations such as uptake, regeneration, nitrification and denitrification. Most estuaries receive high $\mathrm{N}$ loads from anthropogenic activities in the watershed. Depending on the nature of these inputs (agricultural nitrate or organic nitrogen from sewage), this will affect estuarine $\mathrm{N}$ cycling in different ways (Heip \& Herman 1995) and it is therefore necessary to identify DIN and DON pathways. Bacteria are considered the major sink for DON in marine environments (Wheeler \& Kirchman 1986). Studies in estuarine and coastal systems, however, have found that $\mathrm{N}$ uptake in the form of urea is predominantly by phytoplankton rather than by bacteria (Berman \& Bronk 2003 and references therein) but few data exist (Jørgensen 2006). Most previous studies on DON uptake have used batch cultures, and the utilization of DON under in situ conditions is still unclear. Few studies have examined how bacteria and phytoplankton respond to multiple sources of $\mathrm{N}$ under natural conditions. Using stable isotopes and labeling one source at a time makes is possible to study the effect of each substrate under in situ conditions.

The aim of this study was to simulaneously quantify the uptake of DIN, as $\mathrm{NH}_{4}{ }^{+}, \mathrm{NO}_{3}{ }^{-}$and $\mathrm{NO}_{2}{ }^{-}$, and urea and dissolved free amino acids (DFAA) over the whole salinity range of the Scheldt estuary during different seasons. These results could then be compared with concomitant nitrification measurements (Andersson et al. 2006). The importance of DON as a $\mathrm{N}$ or C substrate in natural samples was also investigated in detail using ${ }^{13} \mathrm{C}$ labeled urea and DFAA in parallel with ${ }^{15} \mathrm{~N}$ labeled equivalents.

\section{MATERIALS AND METHODS}

Study area. The Scheldt estuary is located in the SW Netherlands and Belgium and is among the most nutrient-rich systems in the world (Soetaert et al. 2006). The estuary is fed by the Scheldt river, which starts in northern France (St. Quentin) and flows into the North Sea near Vlissingen (The Netherlands). The total catchment area of the Scheldt river is $22000 \mathrm{~km}^{2}$, with a population of more than 10 million people, and containing several large industrial areas. The river is used as a major drain for industrial and domestic wastes, of which a substantial portion is not treated in a wastewater treatment plant. The Scheldt estuary is shallow (mean depth about $10 \mathrm{~m}$ ), turbid and well mixed with a residence time of about 2 mo (Heip 1988). The estuary is about $100 \mathrm{~km}$ long with an area of $300 \mathrm{~km}^{2}$. The tidal amplitude is high, ranging from $3.8 \mathrm{~m}$ in the western to $5.2 \mathrm{~m}$ in the eastern part.

Sampling. Within the VLANEZO (Dutch-Flemish cooperation on sea research) project, 4 cruises were conducted with the RV 'Luctor' in January, April (April B), July and October 2003. Five stations were sampled throughout the salinity range during every cruise: Stns 0, 2, 8, 18 and 28, with the numbers reflecting their salinity (Fig. 1). Water samples were taken with a 201 Niskin bottle from approximately $2 \mathrm{~m}$ depth and were subsampled on board immediately after retrieval of the Niskin bottle. Samples were also taken from 17 fixed monitoring stations along a transect covering the whole salinity gradient from freshwater in the inner estuary to marine conditions at the mouth. Additional data for DON uptake originate from 2 cruises conducted within the EUROTROPH project (Gazeau et al. 2005), 1 in November 2002 and 1 in early April 2003 (April A), 2 wk before the RV 'Luctor' cruise. During these cruises 5 or 6 stations were also sampled, covering the whole salinity range (Fig. 1).

Nutrients. Water was filtered through pre-weighed, pre-combusted Whatman GF/F filters $(47 \mathrm{~mm})$, stored frozen, and analyzed for $\mathrm{NH}_{4}{ }^{+}, \mathrm{NO}_{3}{ }^{-}$and $\mathrm{NO}_{2}{ }^{-}$using 


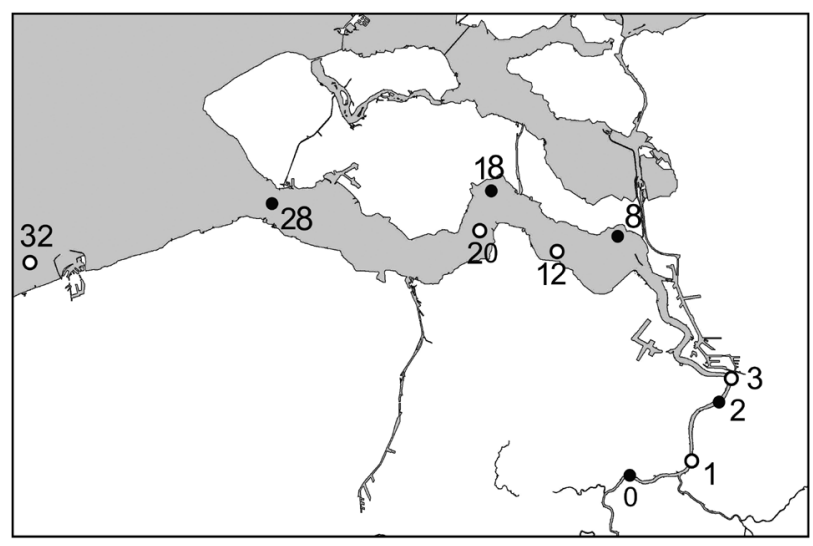

Fig. 1. Scheldt estuary. Numbers show approximate location of the stations and represent their salinity. (•) Stations visited during VLANEZO campaigns; (O) stations visited during EUROTROPH campaigns

automated colorimetric techniques. The filters were weighed for suspended particulate matter (SPM) analysis, and concentrations of particulate organic nitrogen (PON) and carbon (POC) were measured with a Carlo Erba NA 1500 elemental analyzer (Nieuwenhuize et al. 1994). At all stations, salinity, temperature and oxygen were measured. At the VLANEZO stations, DFAA concentrations were measured by HPLC (Fitznar et al. 1999) from the cruises in July and October. Concentrations of urea were measured from the cruises in January, July and October using automated colorimetric techniques (Middelburg \& Nieuwenhuize 2000b). Water was filtered through GF/F filters, which were stored frozen ultil analysis of chlorophyll a ( $\mathrm{chl}$ a) by HPLC (Barranguet et al. 1997).

Nitrification measurement. Nitrification rates were measured using ${ }^{15} \mathrm{~N}$ labeled $\mathrm{NH}_{4}{ }^{+}$as described in Andersson et al. (2006). Briefly, water samples were spiked with ${ }^{15} \mathrm{~N}$ labeled $\mathrm{NH}_{4}{ }^{+}$and, after incubation, the appearance of ${ }^{15} \mathrm{~N}$ in $\mathrm{NO}_{3}^{-}$was measured based on the diffusion technique of Sigman et al. (1997) and Holmes et al. (1998). $\mathrm{NH}_{4}{ }^{+}$and subsequently $\mathrm{NO}_{3}{ }^{-}$ (converted into $\mathrm{NH}_{4}{ }^{+}$using Devarda's alloy) in the sample was trapped on a GF/D filter. The ${ }^{15} \mathrm{~N}$ content of the GF/D filters was determined using a Fisons NA 1500 elemental analyzer coupled to a Finnigan Delta S mass spectrometer via a Conflo II interface.

Uptake measurements. $\mathrm{N}$ uptake was measured using ${ }^{15} \mathrm{~N}$ labeled $\mathrm{NH}_{4}{ }^{+}, \mathrm{NO}_{3}{ }^{-}$and $\mathrm{NO}_{2}{ }^{-}$, urea and a mixture of 17 algal amino acids (Cambridge Isotope Laboratories, NLM-2161). The amino acid mixture consisted of alanine (7\%), arginine $(7 \%)$, aspartic acid $(10 \%)$, glutamic acid $(10 \%)$, glycine $(6 \%)$, histidine $(2 \%)$, isoleucine $(4 \%)$, leucine $(10 \%)$, lysine $(14 \%)$, methionine $(1 \%)$, phenylalanine $(4 \%)$, proline $(7 \%)$, serine $(4 \%)$, threonine $(5 \%)$, tyrosine $(4 \%)$ and valine
( $5 \%$ ) (giving an average $\mathrm{C}: \mathrm{N}$ ratio of 4 in the amino acid mix). Urea and DFAA uptake was also quantified using ${ }^{13} \mathrm{C}$ labeled urea and DFAA with the same composition as mentioned above. The water samples were spiked with the tracer to a final concentration of $0.1 \mu \mathrm{M}$ (except for $1 \mu \mathrm{M}$ of $\mathrm{NO}_{3}{ }^{-}$) and incubated for approximately $2 \mathrm{~h}$ in polystyrene bottles at in situ water temperature in the dark and at ambient light conditions. The incubations were terminated by filtration through pre-combusted $\left(450^{\circ} \mathrm{C}\right.$ for $\left.4 \mathrm{~h}\right)$ Whatman $\mathrm{GF} / \mathrm{F}$ filters (20 mm). The filters were stored frozen until analysis of isotope content of the SPM using a Fisons NA 1500 elemental analyzer coupled to a Finnigan Delta S isotope ratio mass spectrometer (EA-IRMS). Rates for specific uptake $\left(V, \mathrm{~h}^{-1}\right)$ of $\mathrm{NH}_{4}{ }^{+}, \mathrm{NO}_{3}^{-}$and $\mathrm{NO}_{2}^{-}$, urea and DFAA were calculated by dividing the excess ${ }^{15} \mathrm{~N}$ or ${ }^{13} \mathrm{C}$ on the Whatman $\mathrm{GF} / \mathrm{F}$ filter by the excess ${ }^{15} \mathrm{~N}$ or ${ }^{13} \mathrm{C}$ in the solution $\mathrm{h}^{-1}$ incubation time according to Dugdale \& Wilkerson (1986). Absolute uptake rates ( $U$, $\mu$ mol $\mathrm{N}^{-1} \mathrm{~h}^{-1}$ or $\mu \mathrm{mol} \mathrm{C}^{-1} \mathrm{~h}^{-1}$ ) were calculated by multiplying $V$ with PON or POC $\left(\mu \mathrm{mol} \mathrm{l^{-1 }}\right)$, depending on which label was added. The rates reported are average values for light and dark incubations since these showed no statistically significant difference, consistent with previous studies in this and other turbid, tidal estuaries (Middelburg \& Nieuwenhuize $2000 a, b)$. The errors reported herein represent the standard deviation of replicate incubations (in both the dark and light [ $n=4]$, except for January [ $n=2]$. Uptake rates were not corrected for isotope dilution because we lacked measurements, and estimated correction factors (based on the Kanda et al. 1987 approach) were very small, as we have reported earlier (Middelburg \& Nieuwenhuize 2000a,b).

\section{RESULTS}

\section{Concentrations}

The concentration versus salinity plots show the dynamic cycling of nitrogen in the Scheldt estuary (Fig. 2). $\mathrm{NH}_{4}{ }^{+}$concentrations were highest in the inner part of the estuary, with concentrations up to $150 \mu \mathrm{M}$, and then rapidly decreased with increasing salinity. The decrease was highest during July and October. $\mathrm{NO}_{3}{ }^{-}$concentrations in the inner part were around $300 \mu \mathrm{M}$ and either increased or were uniform until a salinity of around 10, thereafter decreasing throughout the estuary. The decrease in $\mathrm{NH}_{4}{ }^{+}$and increase in $\mathrm{NO}_{3}{ }^{-}$in the inner estuary reflect intensive nitrification (Andersson et al. 2006). $\mathrm{NO}_{2}^{-}$levels were low throughout the estuary, with high concentrations (up to $30 \mu \mathrm{M}$ ) in the inner part. Urea and DFAA concentrations varied with season, with a fairly stable concentration 

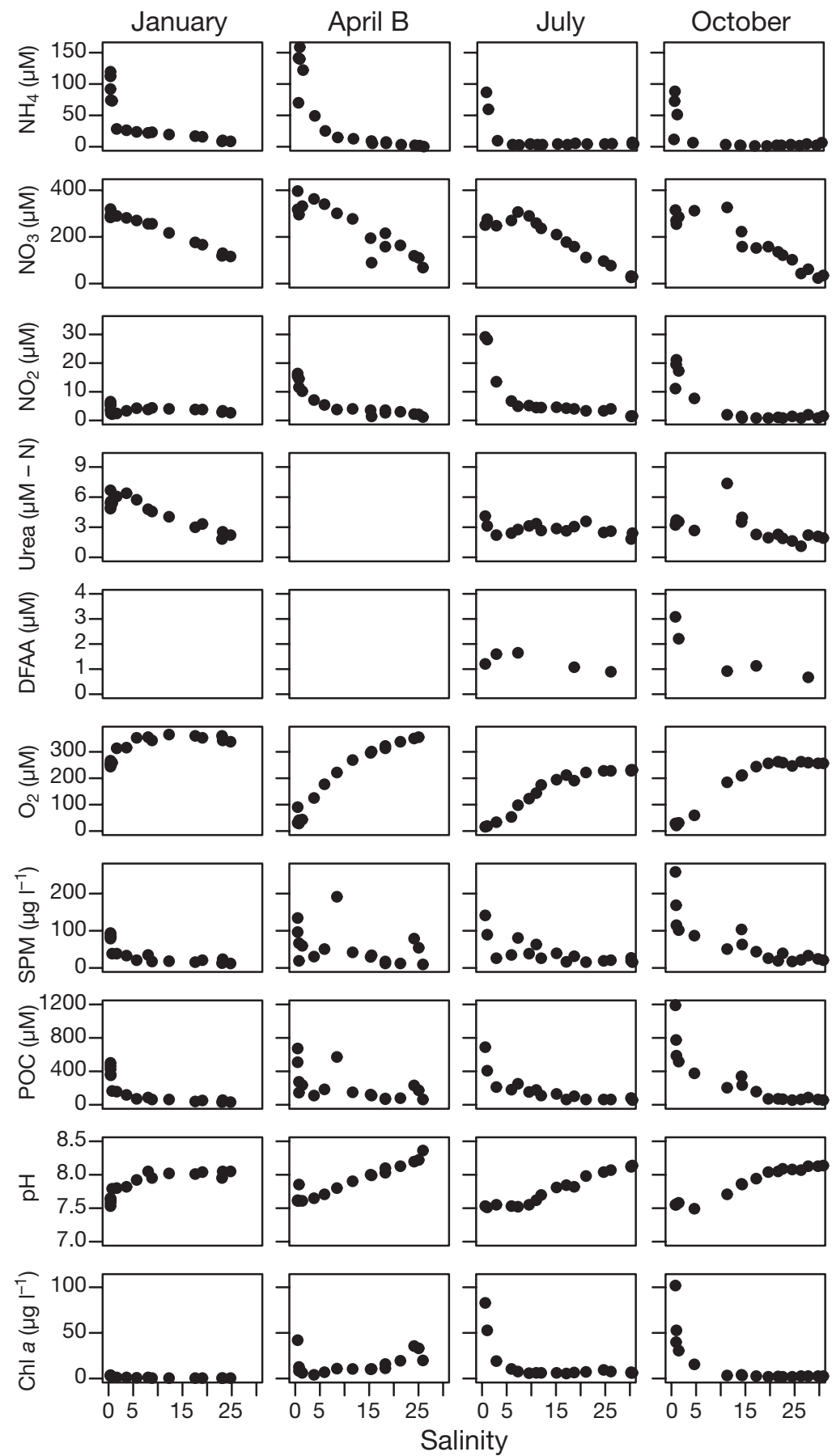

Salinity

Fig. 2. Parameters measured in the Scheldt estuary 2003. Urea was not measured in April B (RV 'Luctor' cuise) and DFAA were not measured in January and April B. Urea is given as $\mu$ mol N-urea $l^{-1}$, DFAA as $\mu$ mol N-DFAA $l^{-1}$. DFAA: dissolved free amino acids; SPM: suspended particulate matter; POC: particulate organic carbon
July and October) in the inner part with increasing concentrations toward the mouth of the estuary, reaching saturation levels and even super saturation $(415 \mu \mathrm{M})$ in April B. SPM varied from $250 \mathrm{mg} \mathrm{l}^{-1}$ in the fall in the inner part of the estuary to $10 \mathrm{mg} \mathrm{l}^{-1}$ in the marine part in January. POC followed the pattern of SPM and varied from $1200 \mu \mathrm{M}$ in the fall at the inner stations to $30 \mu \mathrm{M}$ at the marine stations in January. $\mathrm{pH}$ values were around 7.5 at the inner stations and increased throughout the estuary to above 8 at the marine stations. Chl a levels were below $10 \mathrm{ug} \mathrm{l}^{-1}$ throughout the whole estuary in January and at the more marine stations in July and October. In the inner estuary the concentrations of chl a reached values of up to $100 \mu \mathrm{g} \mathrm{l}^{-1}$ in July and October, and 10 to $40 \mu g \mathrm{l}^{-1}$ were measured throughout the estuary in April B. Comparing algal $\mathrm{C}$ (converted from chl a using a carbon:chl a ratio of 30; Wetsteyn \& Kromkamp 1994) with total POC we obtained a first-order estimate of the algal contribution to the POC pool. A bloom of algae was measured in the marine part of the estuary in April B (Dijkman \& Kromkamp in press), with algae contributing about $75 \%$ to POC. During the other months and in the inner part in April B, algae contributed between 2 and $30 \%$ of the POC, bacteria and detritus accounting for the rest of the POC pool. Dijkman \& Kromkamp (in press) used phospholipidderived fatty acids (PLFA) to measure biomasses of phytoplankton and bacteria during the VLANEZO cruises. These authors showed that in January bacteria were 3 times more abundant than algae while during the other 3 mo bacterial biomass was between one-third and half of algal biomass, with higher biomasses at mid salinities. Accordingly, detritus constituted around $80 \%$ of the POC in January and approximately $50 \%$ during July and October. The water temperature varied with season: 4, 10, 20 and $14^{\circ} \mathrm{C}$ in January, April B, July and October, respectively.

\section{Uptake of DIN and DON}

over the salinity gradient (around $4 \mu \mathrm{M} \mathrm{N}$ for urea, $2 \mu \mathrm{M} N$ for DFAA).

$\mathrm{O}_{2}$ concentration varied between seasons and also along the salinity gradient of the estuary. The general trend was low concentrations (even hypoxic during
There was no significant difference (ANOVA: p-values 0.07 to 0.37 ) between uptake rates measured in the dark and in ambient light. Therefore these data 
Table 1. Uptake rates $\left(\mathrm{nM} \mathrm{h}^{-1}\right)$ of $\mathrm{NH}_{4}{ }^{+}, \mathrm{NO}_{3}{ }^{-}, \mathrm{NO}_{2}{ }^{-}$, urea and DFFA at 5 salinities during 4 seasons. Data are means $\pm \mathrm{SD}$ of 2 replicate samples each from light and dark incubations, except for January when single samples were incubated in light and dark. DFAA: dissolved free amino acids; nd: no data

\begin{tabular}{|c|c|c|c|c|c|c|c|}
\hline Salinity & $\mathrm{NH}_{4}^{+}$ & $\mathrm{NO}_{3}^{-}$ & $\mathrm{NO}_{2}^{-}$ & Urea-N & Urea-C & DFAA-N & DFAA-C \\
\hline \multicolumn{8}{|l|}{ January } \\
\hline 0 & $438 \pm 254$ & $90 \pm 63$ & $32 \pm 24$ & $21 \pm 12$ & $59 \pm 41$ & nd & nd \\
\hline 2 & $195 \pm 17$ & $95 \pm 33$ & $5.7 \pm 2.3$ & $20 \pm 8.8$ & $15 \pm 8.7$ & nd & nd \\
\hline 8 & $154 \pm 101$ & $46 \pm 44$ & $3.7 \pm 2.9$ & $29 \pm 20$ & $39 \pm 55$ & nd & nd \\
\hline 18 & $61 \pm 25$ & $15 \pm 4.8$ & $4.2 \pm 3.4$ & $5.7 \pm 1.3$ & $0.8 \pm 0.5$ & nd & nd \\
\hline 28 & $11 \pm 0.6$ & $8.0 \pm 7.6$ & $1.0 \pm 0.3$ & $2.3 \pm 0.3$ & $1.1 \pm 1.2$ & nd & nd \\
\hline \multicolumn{8}{|l|}{ April B } \\
\hline 0 & $464 \pm 172$ & $66 \pm 6.7$ & $7.4 \pm 3.9$ & nd & nd & nd & nd \\
\hline 2 & $1283 \pm 525$ & $35 \pm 24$ & $5.9 \pm 8.5$ & nd & nd & nd & nd \\
\hline 8 & $248 \pm 26$ & $188 \pm 13$ & $22 \pm 2.0$ & nd & nd & nd & nd \\
\hline 18 & $94 \pm 35$ & $44 \pm 4.9$ & $5.7 \pm 0.8$ & nd & nd & nd & nd \\
\hline 28 & $35 \pm 13$ & $30 \pm 32$ & $2.4 \pm 1.7$ & nd & nd & nd & nd \\
\hline \multicolumn{8}{|l|}{ July } \\
\hline 0 & $452 \pm 146$ & $268 \pm 51$ & $34 \pm 2.0$ & $701 \pm 86$ & $208 \pm 139$ & $195 \pm 44$ & $226 \pm 96$ \\
\hline 2 & $461 \pm 139$ & $161 \pm 51$ & $113 \pm 53$ & $148 \pm 175$ & $6.0 \pm 5.4$ & $110 \pm 18$ & $228 \pm 103$ \\
\hline 8 & $239 \pm 54$ & $87 \pm 36$ & $17 \pm 5.5$ & $58 \pm 43$ & $7.9 \pm 11$ & $66 \pm 10$ & $115 \pm 68$ \\
\hline 18 & $112 \pm 47$ & $35 \pm 22$ & $5.8 \pm 2.3$ & $45 \pm 22$ & $7.0 \pm 9.6$ & $40 \pm 5.0$ & $116 \pm 30$ \\
\hline 28 & $48 \pm 21$ & $7.0 \pm 1.5$ & $2.3 \pm 0.3$ & $30 \pm 9.7$ & $3.7 \pm 4.2$ & $29 \pm 2.3$ & $54 \pm 7.5$ \\
\hline \multicolumn{8}{|l|}{ October } \\
\hline 0 & $348 \pm 122$ & $79 \pm 18$ & $53 \pm 18$ & $93 \pm 37$ & $29 \pm 37$ & $110 \pm 29$ & $775 \pm 355$ \\
\hline 2 & $355 \pm 39$ & $125 \pm 10$ & $55 \pm 11$ & $57 \pm 13$ & $13 \pm 8.9$ & $86 \pm 26$ & $213 \pm 68$ \\
\hline 8 & $43 \pm 7$ & $105 \pm 15$ & $13 \pm 1.0$ & $36 \pm 4.8$ & $10 \pm 11$ & $20 \pm 4.1$ & $55 \pm 23$ \\
\hline 18 & $26 \pm 2.2$ & $36 \pm 5.8$ & $2.0 \pm 0.8$ & $25 \pm 7.8$ & $4.9 \pm 6.1$ & $37 \pm 18$ & $108 \pm 17$ \\
\hline 28 & $1.3 \pm 1.8$ & $6.0 \pm 6.2$ & $1.9 \pm 2.0$ & $11 \pm 12$ & $8.9 \pm 7.1$ & $13 \pm 14$ & $45 \pm 17$ \\
\hline
\end{tabular}

were combined and considered as replicates. With very few exceptions, highest uptake rates were those of $\mathrm{NH}_{4}{ }^{+}$, ranging from $1 \mathrm{nM}$ $\mathrm{h}^{-1}$ at the highest salinity in October to $1 \mu \mathrm{M} \mathrm{h} \mathrm{h}^{-1}$ at Stn 2 in April B (Table 1). There were no clear trends for uptake of any of the substrates, although rates were usually lowest at the mouth of the estuary. Uptake of $\mathrm{NO}_{3}^{-}$ranged from $270 \mathrm{nM} \mathrm{h}^{-1}$ in July to $6 \mathrm{nM} \mathrm{h}^{-1}$ in October. Generally, the lowest uptake was for $\mathrm{NO}_{2}^{-}: 110 \mathrm{nM} \mathrm{h}^{-1}$ in July down to $1 \mathrm{nM} \mathrm{h}^{-1}$ in January. Uptake of urea and DFAA showed rates comparable to and often higher than those of DIN. Urea uptake varied from $700 \mathrm{nM} \mathrm{N} \mathrm{h}^{-1}$ in July to $2 \mathrm{nM} \mathrm{N} \mathrm{h}^{-1}$ in January and DFAA uptake from $200 \mathrm{nM} \mathrm{N} \mathrm{h}^{-1}$ in July to $13 \mathrm{nM} \mathrm{N} \mathrm{h}^{-1}$ in October. Unfortunately, data for DFAA uptake from January and April B were not available. The standard deviation of replicate samples and light/ dark incubations were rather high, in some cases even higher than the measured uptake rate (Table 1).
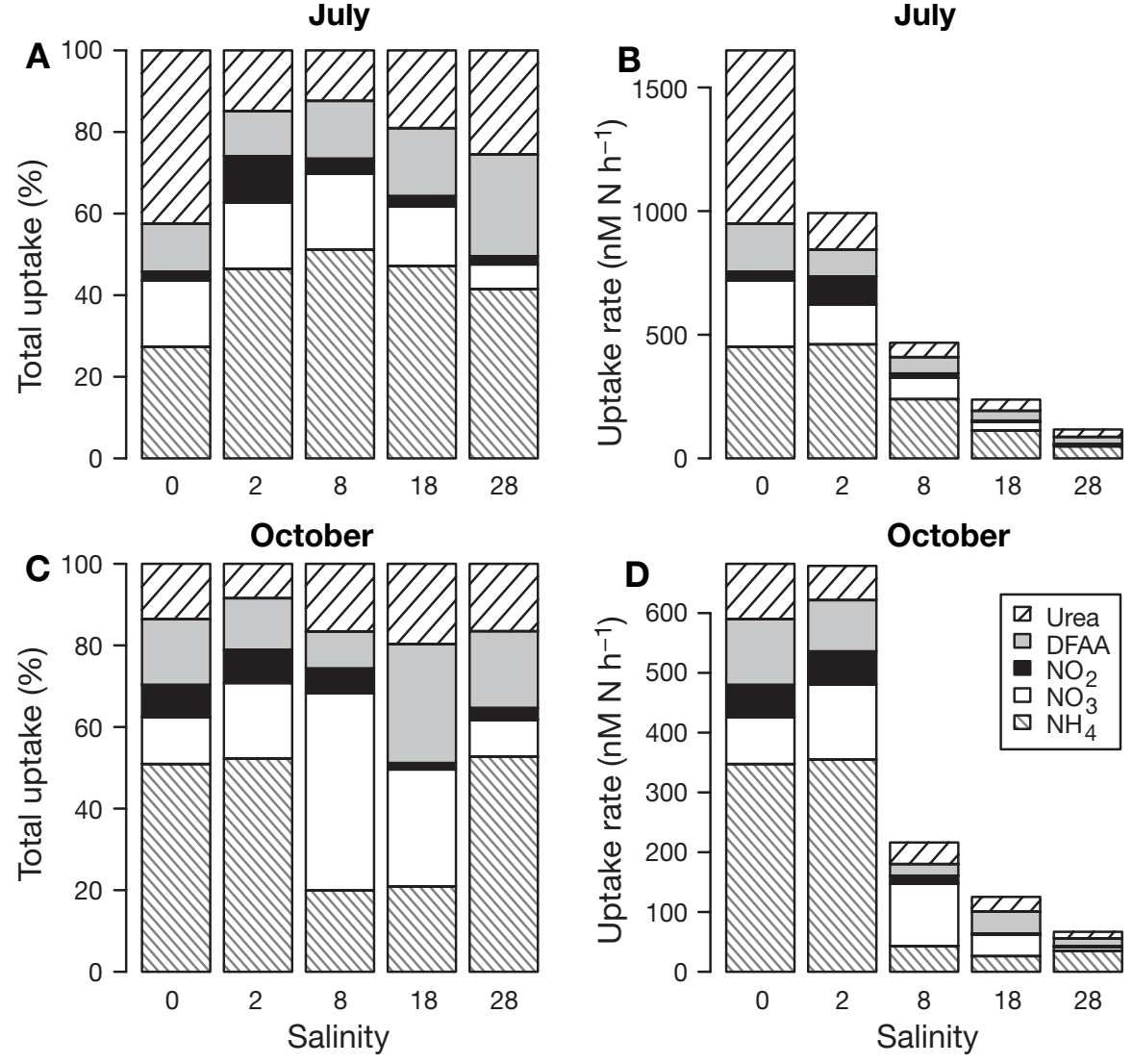

Fig. 3. Relative contribution to $(A, C)$ total uptake and $(B, D)$ uptake rates of the 5 nitrogen sources along the salinity gradient. Note differences in scale for uptake rates 
The relative contribution of the different substrates to their summed uptake varied over the salinity gradient and with season (Fig. 3A, C). In July $\mathrm{NH}_{4}{ }^{+}$made its highest contribution at Stn 8 (51\%), with values decreasing both toward the inner estuary and the mouth of the estuary. A completely opposite pattern was found in October, when the lowest relative contribution was at $\mathrm{Stn} 8$, with $\mathrm{NO}_{3}{ }^{-}$showing the highest contribution (48\%). Urea showed a contrasting pattern to $\mathrm{NH}_{4}{ }^{+}$, being highest in July at Stn 0 (43\%), and DFAA displayed its highest relative importance (up to $29 \%$ ) at the more marine stations. The relative contribution of $\mathrm{NO}_{2}{ }^{-}$was low throughout the estuary (11\% at highest) with lowest values at the mouth $(2 \%)$. The absolute uptake rates were higher at stations with lower salinities (Fig. 3B,D). Uptake of $\mathrm{NH}_{4}{ }^{+}$and $\mathrm{NO}_{3}{ }^{-}$was similar in July and October while uptake of urea was higher in July, resulting in a higher total $\mathrm{N}$ uptake in July.

\section{Uptake of dissolved organic matter}

Absolute uptake rates of urea and DFAA are only available for the July and October cruises (Table 1, Fig. 3). However, for all cruises results can be presented as excess ${ }^{15} \mathrm{~N}$ or ${ }^{13} \mathrm{C}$ after incubation $\left(\mathrm{nM} \mathrm{h}^{-1}\right)$, and these allow a direct comparison of $\mathrm{N}$ and $\mathrm{C}$ uptake. The re- gression lines in Fig. 4 show the expected relationship between excess ${ }^{13} \mathrm{C}$ and ${ }^{15} \mathrm{~N}$ were the whole urea molecule (with a $\mathrm{C}: \mathrm{N}$ ratio of 0.5 ) to be taken up and both $\mathrm{C}$ and $\mathrm{N}$ to remain in the cell and be assimilated during the $2 \mathrm{~h}$ incubation. Large differences can be seen for the 6 sampling occasions (Fig. 4). In November and January urea uptake rates were low and urea was mainly used as a C source. In early spring, April A uptake of urea was lower than later the same month, April B. In July the highest utilization of urea was measured, with rates decreasing again in October. Throughout April to October urea was used as a substrate for both $\mathrm{N}$ and C. Moreover, no differences were found for samples incubated in ambient light and samples incubated in the dark (data not shown).

The algal amino acid mixture used in this study had on average a $\mathrm{C}: \mathrm{N}$ ratio of 4 ; the regression lines in Fig. 5 represent the values expected if the whole amino acid molecule were taken up and both $\mathrm{C}$ and $\mathrm{N}$ assimilated. DFAA utilization of $\mathrm{N}$ and $\mathrm{C}$ was diametrically to that of urea. In November, January and April the whole molecule seems to have been used. Later in the season, particularly in July and October, there was a shift toward using DFAA as a N substrate. Remarkably, those months with low urea uptake (January, April A and November) all had a higher uptake of DFAA than the other 3 mo.
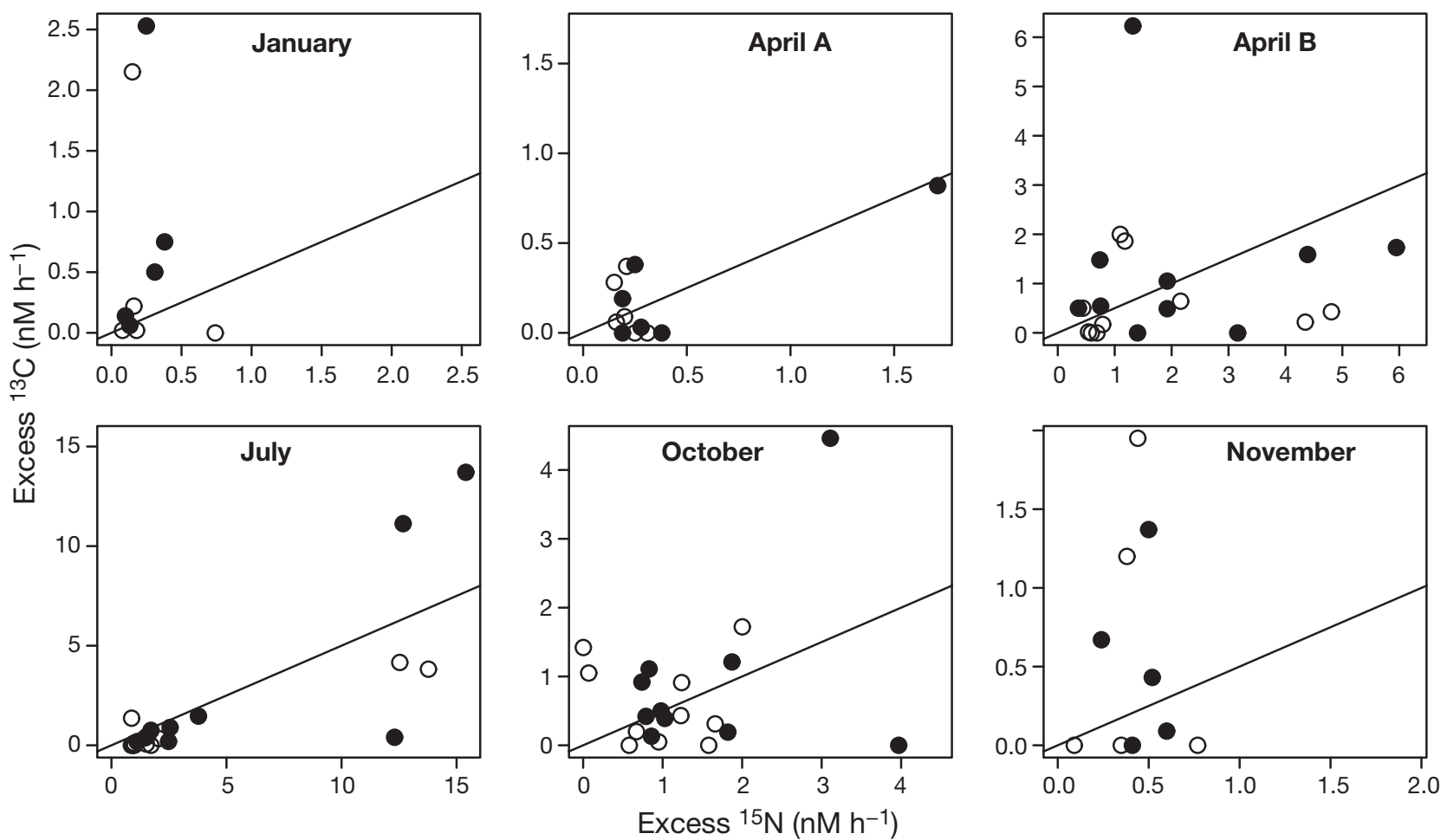

Fig. 4. Excess ${ }^{13} \mathrm{C}$ vs. excess ${ }^{15} \mathrm{~N}$ during incubations with labeled urea. Uptake in ambient light (O) and in the dark (•). Regression line shows value expected if a complete urea molecule, with $\mathrm{C}: \mathrm{N}$ ratio of 0.5, were taken up. April A: EUROTROPH project, 2 wk before April B sampling by RV 'Luctor' 

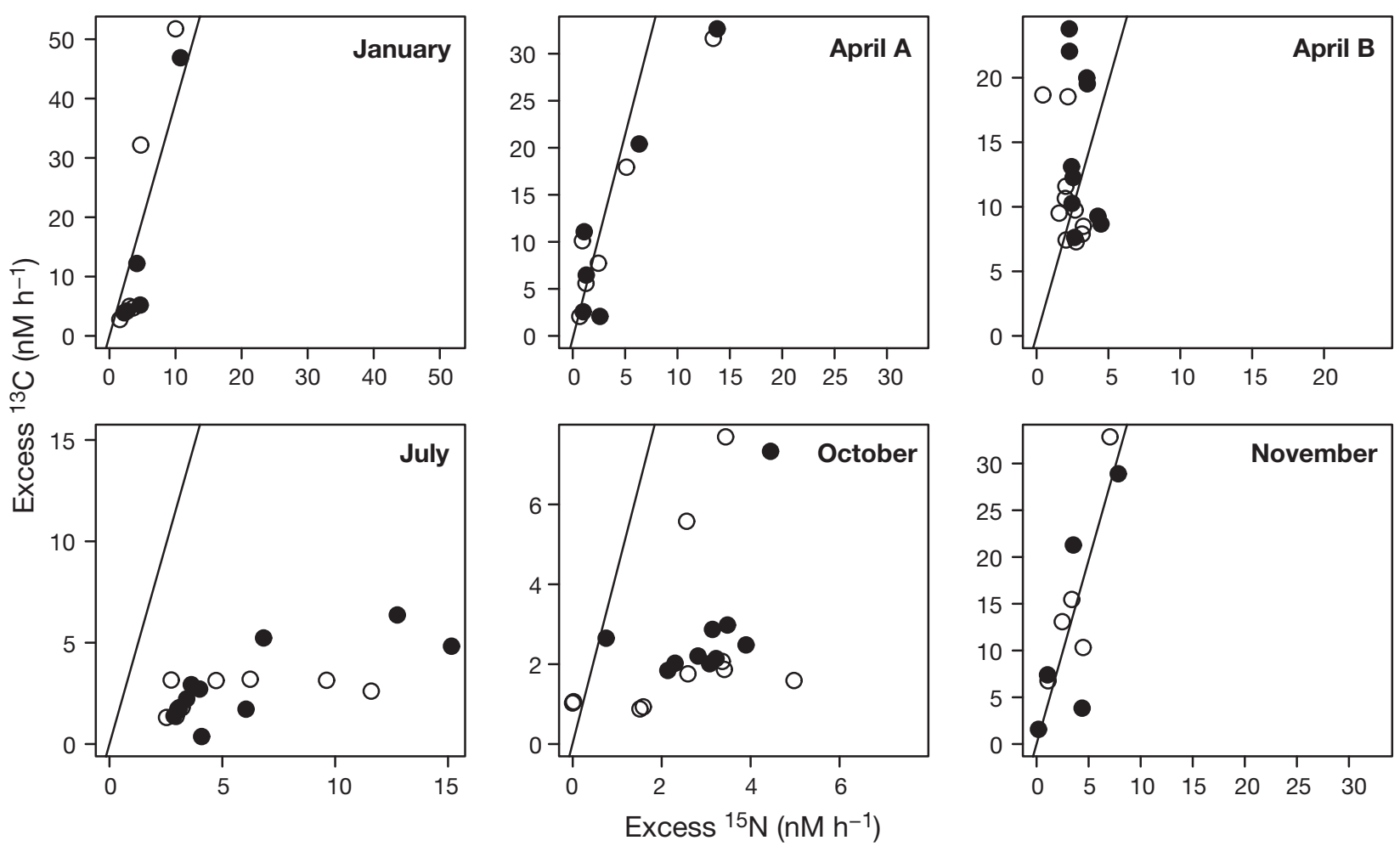

Fig. 5. Excess ${ }^{13} \mathrm{C}$ vs. excess ${ }^{15} \mathrm{~N}$ during incubations with labeled DFAA. Uptake in ambient light (O) and in the dark $(\bullet)$. Regression line shows value expected if a whole average amino acid molecule, with C:N ratio of 4 were taken up. April A: EUROTROPH project, 2 wk before April B sampling by RV 'Luctor'

\section{Nitrification}

Highest nitrification activity was measured in the inner part of the estuary, with rates decreasing toward the mouth. Nitrification was generally higher in July and October, corresponding to higher temperature and lower $\mathrm{NH}_{4}{ }^{+}$concentration, which ranged from 700 in October to $150 \mathrm{nM} \mathrm{h}^{-1}$ in April B in the freshwater stations and from $20 \mathrm{nM} \mathrm{h}^{-1}$ to undetectable in the marine stations. Nitrification rates were in the same order of magnitude as $\mathrm{NH}_{4}{ }^{+}$uptake rates. The most obvious difference was at Stns 0 and 2 in April $\mathrm{B}$, when $\mathrm{NH}_{4}{ }^{+}$ uptake was much higher than both nitrification and $\mathrm{NO}_{3}{ }^{-}$uptake (Fig. 6).

\section{DISCUSSION}

The Scheldt estuary is a turbid, tidal, heterotrophic system (Goosen et al. 1999, Boschker et al. 2005) with high nutrient concentrations and organic loading (Kromkamp et al. 1995). Algal C constituted a small part of the POC (on average $15 \%$ during our study) and bacteria were 3 times more abundant than algae in January while during the other months bacterial biomass made up between one-third and half of the algal bio- mass (Dijkman \& Kromkamp in press). Input of allochthonous organic matter and nutrients in the inner estuary are high (Kromkamp et al. 1995), and during our study most $\mathrm{N}$ pools did not show a conservative behavior due to mixing (Fig. 2) during transport to the sea, but were clearly affected by processes within the estuary. Two major transformation pathways for $\mathrm{NH}_{4}{ }^{+}$in the estuary are nitrification, whereby $\mathrm{NH}_{4}{ }^{+}$is oxidized to $\mathrm{NO}_{3}{ }^{-}$via $\mathrm{NO}_{2}{ }^{-}$, and uptake by phytoplankton and bacteria. $\mathrm{NO}_{3}{ }^{-}$and $\mathrm{NO}_{2}{ }^{-}$can also be taken up by phytoplankton and bacteria or be denitrified to $\mathrm{N}_{2}$ gas (in the sediment). Urea and DFAA can be taken up by phytoplankton and bacteria as a substrate for N, C, or both.

Comparison of our $\mathrm{NH}_{4}{ }^{+}$uptake rates with parallel measurements of nitrification rates during the same cruises (Andersson et al. 2006) shows them to be of the same order of magnitude (Fig. 6). The ratio of $\mathrm{NH}_{4}{ }^{+}$ uptake to nitrification ranges from 0.5 to 25 (where 1 represents equal uptake and nitrification rates). In April $\mathrm{B}$, during the spring bloom, $\mathrm{NH}_{4}{ }^{+}$uptake was much higher than $\mathrm{NH}_{4}{ }^{+}$oxidation by the nitrifiers. In July the community of nitrifiers had had time to develop, and roughly the same amount of $\mathrm{NH}_{4}{ }^{+}$was taken up as was nitrified. There are few parallel studies of nitrification and $\mathrm{NH}_{4}{ }^{+}$uptake. Lipschultz et al. (1986) showed nitrification to be the major process 


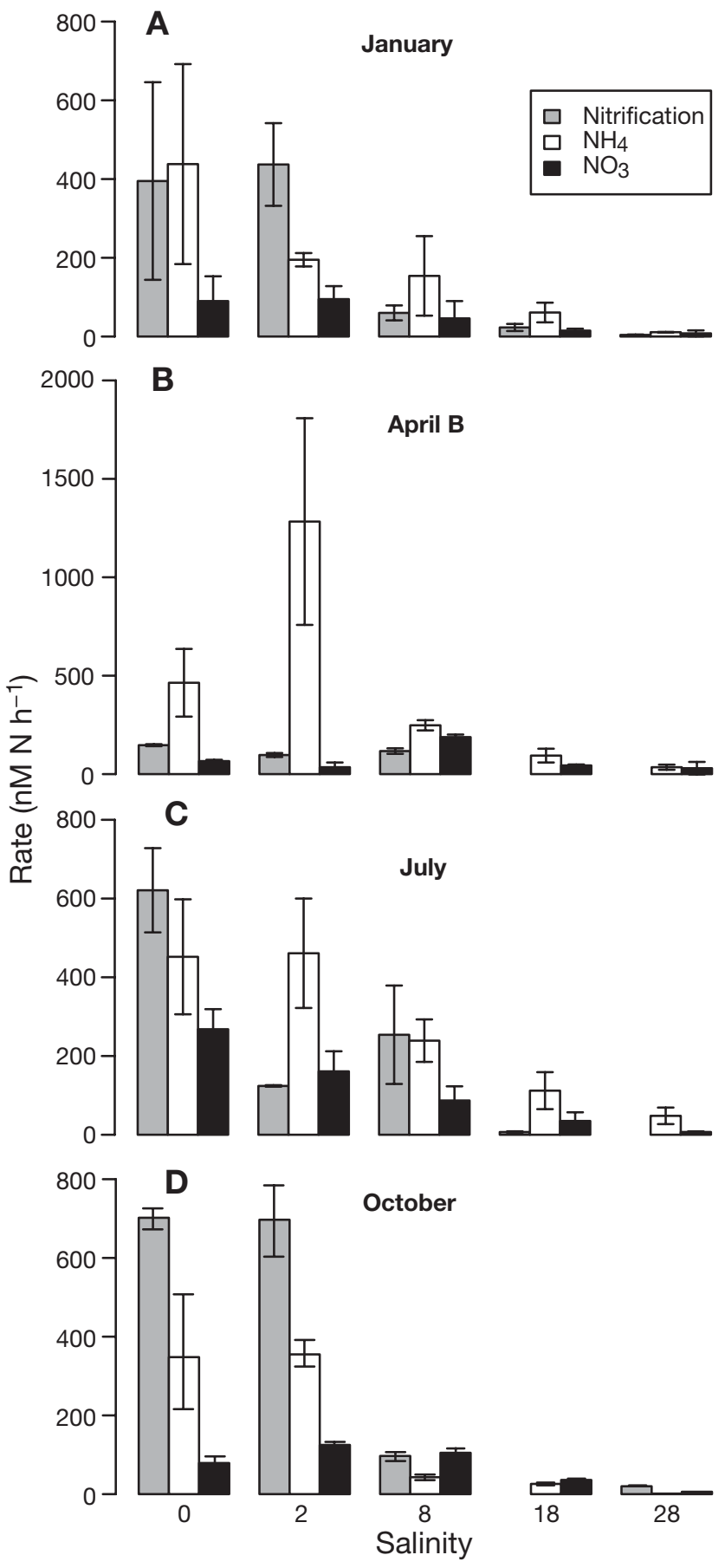

Fig. 6. Nitrification rate and uptake rates of $\mathrm{NH}_{4}{ }^{+}$and $\mathrm{NO}_{3}{ }^{-}$ during $4 \mathrm{mo}$ in 2003 at 5 different salinities. Note scale for April B is twice that for the other 3 mo

affecting $\mathrm{NH}_{4}{ }^{+}$distribution in the Delaware River. Ward (2005) investigated $\mathrm{NH}_{4}{ }^{+}$oxidation and assimilation in the upper $70 \mathrm{~m}$ of Monterey Bay, California, USA, an eastern boundary upwelling system, and found that $\mathrm{NH}_{4}{ }^{+}$assimilation was much larger than $\mathrm{NH}_{4}{ }^{+}$oxidation in the upper $25 \mathrm{~m}$, but that rates were similar at greater depths. Depth-integrated rates of
$\mathrm{NH}_{4}{ }^{+}$assimilation $\left(5.1 \mu \mathrm{mol} \mathrm{m}{ }^{-2} \mathrm{~d}^{-1}\right)$ were higher than those of $\mathrm{NH}_{4}{ }^{+}$oxidation $\left(2.0 \mu \mathrm{mol} \mathrm{m}{ }^{-2} \mathrm{~d}^{-1}\right)$. Comparison of the $\mathrm{NO}_{3}{ }^{-}$production rate via nitrification with the $\mathrm{NO}_{3}^{-}$uptake rate (Fig. 6) revealed that, with a few exceptions, most $\mathrm{NO}_{3}^{-}$produced via nitrification was not taken up, consistent with the $\mathrm{NO}_{3}{ }^{-}$vs. salinity plots of net $\mathrm{NO}_{3}{ }^{-}$production in Fig. 2 .

Uptake rates in the light were not significantly different from those in the dark for all substrates and light and dark incubation data were therefore combined. This similarity between light and dark uptake rates has been reported before, in particular for turbid systems with relatively low algal biomass and high concentrations of bacteria with respect to total community uptake (Middelburg \& Nieuwenhuize 2000a,b). The Scheldt estuary is a prototype heterotrophic, turbid estuary in which particle-attached bacteria play a dominant role in moderating $\mathrm{C}$ and $\mathrm{N}$ flows (e.g. Boschker et al. 2005). Partitioning of nitrogen uptake between phytoplankton and heterotrophic bacteria in turbid estuaries such as the Scheldt Estuary is difficult, since size fractionation by pre- or post-incubation filtration is not feasible because of filter clogging and is not appropriate because of the tight association of the bacteria with particles. Alternatively, prokaryotic inhibitors might be used to distinguish between eukaryotic and prokaryotic activity, although these are never $100 \%$ selective or $100 \%$ effective (Oremland \& Capone 1988). Although we have already used this approach successfully in the turbid Loire and Thames estuaries (Middelburg \& Nieuwenhuize 2000a,b), we obtained highly variable, inconclusive results in the Scheldt estuary. We were therefore unable to partition nitrogen uptake among the bacteria and phytoplankton but, given the lack of light-dark differences, the heterotrophic status of this estuary, and its high bacterial biomass (Boschker et al. 2005), we believe bacteria to be the major contributors to the nitrogen uptake.

In regard to the absolute uptake rates of the different substrates, the rates of $\mathrm{NH}_{4}{ }^{+}$uptake were highest, with a few exceptions, partly due to the much higher concentrations of $\mathrm{NH}_{4}{ }^{+}$compared to DFAA and urea. To investigate preference for different substrates, many authors (Fan et al. 2003, Phillips \& Hurd 2003, Weston et al. 2004, Bode et al. 2005) have used the relative preference index (RPI) (McCarthy et al. 1977), defined as

$$
\mathrm{RPI}_{X}=\frac{U_{X}}{\sum U} / \frac{C_{X}}{\sum C}
$$

where $\mathrm{RPI}_{X}=$ relative preference index of Substrate $X_{\text {, }}$ $U_{X}=$ uptake rate of Substrate $x, C_{X}=$ concentrations of Substrate $x$ and and $\Sigma U$ and $\Sigma C=$ the summed uptake and concentration, respectively, for all substrates (i.e. $\mathrm{NH}_{4}{ }^{+}, \mathrm{NO}_{3}^{-}, \mathrm{NO}_{2}^{-}$, urea and DFAA). The RPI for the 

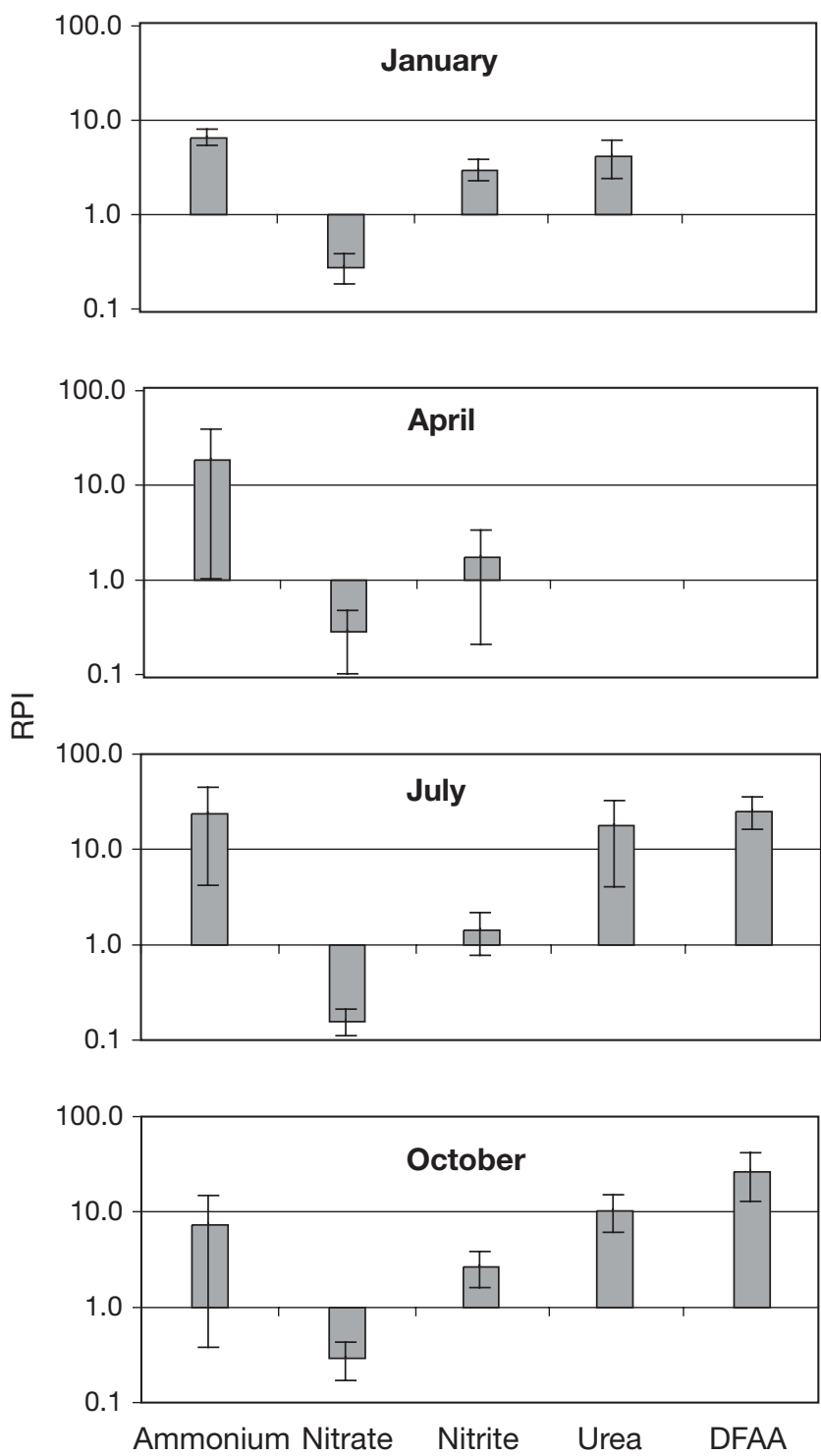

Fig. 7. Relative preference index (RPI) values, averaged over the salinity gradient, for $\mathrm{NH}_{4}{ }^{+}, \mathrm{NO}_{3}{ }^{-}, \mathrm{NO}_{2}{ }^{-}$, urea and DFAA in the Scheldt estuary during 2003

different substrates is shown in Fig. 7. An RPI of 1 reflects utilization equal to availability, $>1$ preference for a substrate, and $<1$ preference against that substrate. Our results clearly show that $\mathrm{NO}_{3}{ }^{-}$is the least preferred substrate (Fig. 7) with RPI values $<1$ in all seasons, implying that it would be used only if other forms of $\mathrm{N}$ were less available. Urea and DFAA have RPI values in the same range as, or higher than, those of $\mathrm{NH}_{4}{ }^{+}$, which means that these substrates are used to the same extent when equally available. $\mathrm{NO}_{2}{ }^{-}$was less preferred than $\mathrm{NH}_{4}{ }^{+}$, urea and DFAA, but more preferred than $\mathrm{NO}_{3}{ }^{-}$. The utilization of RPI has been questioned as being strongly dependent on substrate concentration and weakly related to physiological preferences (Dortch 1990, Stolte \& Riegman 1996). This could be the case for our finding of $\mathrm{NO}_{3}{ }^{-}$rejection arising from high $\mathrm{NO}_{3}{ }^{-}$concentration, but the differences recorded for the other substrates were likely due to physiological preferences, since their concentrations were similar (except for $\mathrm{NH}_{4}{ }^{+}$in the freshwater).

Our uptake rates are similar to and often higher than previous rates recorded in the literature for estuarine systems. Our uptake rates of $\mathrm{NH}_{4}{ }^{+}$and $\mathrm{NO}_{3}{ }^{-}$fall within the range found by Middelburg \& Nieuwenhuize (2000a) in 6 turbid, tidal estuaries including the Scheldt estuary. Other studies showed lower uptake of $\mathrm{NH}_{4}{ }^{+}$and higher or similar uptake of $\mathrm{NO}_{3}{ }^{-}$(Lipschultz et al. 1986, Bronk \& Glibert 1993, Bronk et al. 1998, Middelburg \& Nieuwenhuize 2000b, Veuger et al. 2004), corresponding to lower and higher substrate concentrations, respectively. The uptake rates of urea and DFAA in our study are within the range reported in an extensive comparison of urea and DFAA uptake rates from various systems by Bronk (2002), and compare best to rates found in the Chesapeake Bay estuary. The importance of urea as a $\mathrm{N}$ substrate varies (depending on the system) from 5 to $64 \%$ of total $\mathrm{N}$ uptake (Bronk 2002) and on average urea contributes more to total $\mathrm{N}$ uptake than does DFAA. DFAA contributes approximately $10 \%$ to total $\mathrm{N}$ uptake (Bronk 2002), but can contribute more than this, e.g. in the marine part of the Thames estuary DFAA accounted for about $90 \%$ of total $\mathrm{N}$ uptake (Middelburg \& Nieuwenhuize 2000b). In the Scheldt estuary, urea contributed between 8 and $43 \%$ and DFAA between 9 and $29 \%$ to total N uptake in July and October (the only months where absolute uptake rates for urea and DFAA were available).

DON comprises a diverse mixture of compounds such as proteins, oligopeptides, purines, nucleic acids and humic substances. Usually $<20 \%$ of the DON pool can be identified, including urea and DFAA, while up to $70 \%$ of DON is often potentially bioavailable (Seitzinger et al. 2002, Stepanauskas et al. 2002). Since urea and DFAA constitute a small fraction of DON, we have very likely underestimated total DON uptake using our approach. In previous studies, 7 to $30 \%$ of DON uptake arose from urea utilization in the spring and $74 \%$ in the fall (Bronk \& Glibert 1993). Despite our likely underestimation of total DON uptake, it is obvious that calculation of DON uptake is necessary for accurate quantification of total $\mathrm{N}$ uptake and that some of the compounds within the DON pool are used preferentially. A few previous studies using ${ }^{15} \mathrm{~N}$ labeled DON found that this complex DON was taken up in the same order of magnitude as DIN (Bronk \& Glibert 1993, Veuger et al. 2004). When studying the importance of total ambient DON as a source of $\mathrm{N}$ compared to DIN, this may be a more useful approach, whereas 
the use of individual DON compounds such as urea and DFAA can increase our knowledge of the mechanisms behind DON uptake.

Having shown urea and DFAA to be similar in importance to DIN for microbial $\mathrm{N}$ acquisition, we further investigated whether urea and DFAA constitute a $\mathrm{N}$ substrate only, or if they also can be used as an energy source. It has been shown that both heterotrophic bacteria (Middelboe et al. 1995, Rosenstock \& Simon 2001) and microalgae (Palenik \& Morel 1990, Bronk \& Glibert 1993, Berman \& Chava 1999, Fan \& Glibert 2005, Linares 2006) utilize DON, although the questions as to how, why and when they do so remain unclear. Utilization of urea requires energy, since urease needs to be synthesized to enable hydrolyzation of this substrate. The importance of urea as a $\mathrm{N}$ source for phytoplankton and bacteria has been well documented (Berman \& Bronk 2003, Jørgensen 2006). However, the importance of urea as a $\mathrm{C}$ source is unclear, and has been studied rarely and with contradictory results (Petersen et al. 2004, Jørgensen 2006). In the $1980 \mathrm{~s}$, investigators used radioactive ${ }^{14} \mathrm{C}$ labeled urea in parallel with ${ }^{15} \mathrm{~N}$ labeled urea (Price \& Harrison 1988 and references therein) to measure urea uptake, and an uncoupling between $\mathrm{N}$ and $\mathrm{C}$ uptake from urea was often found. More recent literature has also shown variable results, depending on the system or organism studied. During a bloom of a brown tide pelagophyte on the east coast of the USA, urea was used as a source for $\mathrm{N}$ but not for $\mathrm{C}$ (Mulholland et al. 2004). However, during a bloom of a dinoflagellate in Chesapeake Bay, urea was used mostly as a source of $\mathrm{C}$ (with a molar C:N uptake ratio of 2.3; Fan \& Glibert 2005), indicating greater retention of $\mathrm{C}$ than $\mathrm{N}$. During phytoplankton blooms, uptake measurements of DFAA have shown that these are used as a substrate for $\mathrm{N}$ as well as $\mathrm{C}$ to a variable extent (Mulholland et al. 2002).

One urea molecule contains $1 \mathrm{C}$ and $2 \mathrm{~N}$ atoms and, when taken up, is split into $1 \mathrm{CO}_{2}$ molecule and $2 \mathrm{NH}_{4}{ }^{+}$ molecules by the enzyme urease (Price \& Harrison 1988, Mobley \& Hausinger 1989, Zehr \& Ward 2002). If urea were utilized as a whole molecule, $2 \mathrm{~N}$ atoms per $1 \mathrm{C}$ atom would be taken up (indicated by regression line in Fig. 4). Our results for urea uptake were not easily interpreted. In January and November, C was incorporated to a much larger extent than would be expected through uptake of whole molecules, implying that $\mathrm{N}$ was released, probably as $\mathrm{NH}_{4}{ }^{+}$. In the other months the data generally followed the same trend as for uptake of the whole molecule and we thus cannot conclude that urea was used preferentially as a source of $\mathrm{N}$ or $\mathrm{C}$. Additional research will be required to attain a more complete understanding of the utilization of urea as a substrate for $\mathrm{N}$ and $\mathrm{C}$.
The importance of DFAA for N uptake has been well studied (Wheeler \& Kirchman 1986, Palenik \& Morel 1990, Hoch \& Kirchman 1995, Nilsson \& Sundbäck 1996, Middelburg \& Nieuwenhuize 2000b, Mulholland et al. 2002), and a few studies have addressed the question as to whether DFAA constitute a $\mathrm{N}$ or a C source (Jørgensen et al. 1993, 1999, Middelboe et al. 1995, Mulholland et al. 2002). Bacteria are still considered to be most important for DFAA uptake (Hoch \& Kirchman 1995); however, it is now apparent that many phytoplankton also can use DFAA as N source (Berman \& Bronk 2003). DFAA can be incorporated via direct uptake of the whole molecule or can be oxidized extracellularly and the released $\mathrm{NH}$ and organic carbon can subsequently utilized (uncoupled uptake). To our knowledge Mulholland et al. (2002) were the first to use dually labeled DFAA to estimate $\mathrm{C}$ and $\mathrm{N}$ uptake by natural communities of the algae Aureococcus anophagefferens. These authors showed both coupled and uncoupled uptake in this pelagophyte, with DFAA constituting $50 \%$ of the total N uptake and about half of the associated $\mathrm{C}$ being taken up. In a later study, Mulholland et al. (2003) found uncoupled uptake rates of DFAA C and N, with DFAA N being taken up preferentially to $\mathrm{C}$ along an estuarine gradient in the Chesapeake Bay. In Lake Constance, Germany, DFAA and protein supported 58 and $80 \%$ of the bacterial $\mathrm{C}$ and $\mathrm{N}$ demand, respectively, making them the most important bacterial $\mathrm{C}$ and $\mathrm{N}$ sources (Rosenstock \& Simon 2001). Using a combination of ${ }^{15} \mathrm{~N}$ and ${ }^{13} \mathrm{C}$ labeled DFAA it is possible to distinguish between uptake of the whole molecule and stoichiometric assimilation on the one hand and partial uptake or selective assimilation of $\mathrm{N}$ or $\mathrm{C}$ on the other hand.

Our results support previous findings that DFAA are used as a source for both $\mathrm{C}$ and $\mathrm{N}$. Moreover we observed seasonal variation in the coupling or uncoupling of $\mathrm{N}$ or $\mathrm{C}$ uptake. The regression lines in Fig. 5 show the ratio expected between $\mathrm{C}$ and $\mathrm{N}$ uptake if the whole amino acid molecule were utilized (based on an average C:N ratio of 4 in the labeled algal mixture). In January, April and November, the uptake data were scattered around this line, indicating that DFAA were used as both a $\mathrm{N}$ source and a $\mathrm{C}$ source. In July and October, DFAA were used as a $\mathrm{N}$ rather than a $\mathrm{C}$ source, likely through extracellular amino acid oxidation. It should be noted, however, that the activities were lower during these months. The most striking difference between July and October and the other months was the availability of $\mathrm{NH}_{4}^{+}$(Fig. 2). When $\mathrm{NH}_{4}{ }^{+}$availability was low, bacteria, phytoplankton or both utilized the N content of DFAA to a larger extent. High amino acid oxidase activities in phytoplankton have been shown to coincide with low $\mathrm{NH}_{4}{ }^{+}$levels and with high biomass levels indicating an algal bloom (Mulholland et al. 1998). Furthermore, Pantoja \& Lee 
(1994) showed that extracellular amino acid oxidation only occurs at higher temperature, consistent with our findings that in July and October the $\mathrm{N}$ portion of the DFAA was preferentially used.

Urea and DFAA may be preferred as substrates under limited growth conditions, such as reduced light intensity or lowered temperature (Berg et al. 1997), since they can supply the cell with both organic $\mathrm{C}$ and $\mathrm{N}$. This might explain why in November, January and April DFAA were particularly used as a source of both $\mathrm{C}$ and N (Fig. 5). During these months low water temperature and reduced light were limiting autotrophic growth. During the months when DFAA were used as a source for both $\mathrm{N}$ and $\mathrm{C}$, urea was, in general, used primarily as a $\mathrm{C}$ source. When uptake rates of DFAA were high (in January, April A and November), uptake rates of urea were lower than in the other 3 mo. This seasonal variability might be related to seasonal changes in the community of phytoplankton and bacteria, but nutrient concentrations, light availability, oxygen conditions also vary during the year.

Since the $\mathrm{C}$ and $\mathrm{N}$ of urea and DFAA may or may not be taken up in proportion to their occurrence, and since this may depend on the organisms involved (photoautotrophs vs. heterotrophs) and their physiological status, C-based uptake rates cannot always be converted into $\mathrm{N}$ units, or vice versa. The use of dually labeled substrates is necessary to increase our insight into the role of DON cycling in pelagic ecosystems and to further our understanding of DON acquisition strategies by microbes. To take this relatively unexplored field of research one step further and study in detail which organisms are involved in the uptake of inorganic versus organic substrates, biomarkers such as PLFA (Boschker \& Middelburg 2002, Petersen et al. 2004) and D-alanine (Veuger et al. 2005) can be valuable tools in combination with dually labeled substrates. Heterotrophs (bacteria) and photoautotrophs differ with respect to their uptake of $\mathrm{C}$ and N. Photoautotrophs can assimilate DIC during photosynthesis in the light and incorporate $\mathrm{N}$ throughout the entire day, resulting in a temporarily uncoupled uptake of $\mathrm{C}$ and N. Heterotrophs grow on organic substrates and usually take up $\mathrm{C}$ and $\mathrm{N}$ at the same time, but their relative use of $\mathrm{C}$ and $\mathrm{N}$ may differ. It is likely that during the summer months uptake by photoautotrophs was more important in our study than during the other months, since uptake rates of $\mathrm{C}$ and $\mathrm{N}$ in DFAA were uncoupled. During the other months heterotrophic uptake may have been of greater importance. This is consistent with the findings of Dijkman \& Kromkamp (in press), especially for January, when bacteria were more abundant than in the other months. Organisms that are most suited to utilize DON are mixotrophs, which can use inorganic nutrients and light energy (as photoautotrophs) for growth during the day, and organic substrates for both nutrients and energy (as heterotrophs) during the day and night (Mulholland et al. 2004). The Scheldt estuary constitutes a perfect environment for such organisms, with limited light availability below the surface and both high nutrient and DOM availability.

\section{CONCLUSIONS}

DON uptake contributes significantly to total $\mathrm{N}$ uptake by natural estuarine communities and should therefore be included in $\mathrm{N}$ uptake studies. Like urea and DFAA, it can constitute a source for both $\mathrm{N}$ and $\mathrm{C}$, and thus the use of single labeled substrates might result in a biased uptake estimate and incomplete understanding of DON cycling.

The uptake of $\mathrm{C}$ and $\mathrm{N}$ from DON varies seasonally: in January, April and November, C is taken up to a larger extent than during July and October, periods when $\mathrm{NH}_{4}{ }^{+}$availability is relatively low. Rates of nitrification and uptake of $\mathrm{NH}_{4}^{+}$are of similar magnitude.

Acknowledgements. We thank P. van Breugel, M. Houtkamer, C. Kleppe-van Zetten, Y. van der Maas, J. Nieuwenhuize and J. Sinke for analytical and sampling support, and the crew of the RV 'Luctor' for help and assistance during sampling. We thank 4 anonymous reviewers for constructive feedback. This study was supported by the Flemish-Dutch cooperation funds for Sea Research (NWO 832.11.002 and 832.11.007) and by the European Union (EUROTROPH, EKV3-CT-2000-00040). This is publication 3867 of the Netherlands Institute of Ecology (NIOO-KNAW).

\section{LITERATURE CITED}

Andersson MGI, Brion N, Middelburg JJ (2006) Comparison of nitrifier activity versus growth in the Scheldt estuarya turbid, tidal estuary in northern Europe. Aquat Microb Ecol 42:149-158

Barranguet C, Herman PMJ, Sinke JJ (1997) Microphytobenthos biomass and community composition studied by pigment biomarkers: importance and fate in the carbon cycle of a tidal flat. J Sea Res 38:59-70

Berg GM, Glibert PM, Lomas MW, Burford MA (1997) Organic nitrogen uptake and growth by the chrysophyte Aureococcus anophagefferens during a brown tide event. Mar Biol 129:377-387

Berg GM, Repeta DJ, Laroche J (2002) Dissolved organic nitrogen hydrolysis rates in axenic cultures of Aureococcus anophagefferens (Pelagophyceae): comparison with heterotrophic bacteria. Appl Environ Microbiol 68:401-404

Berman T, Bronk DA (2003) Dissolved organic nitrogen: a dynamic participant in aquatic ecosystems. Aquat Microb Ecol 31:279-305

Berman T, Chava S (1999) Algal growth on organic compounds as nitrogen sources. J Plankton Res 21:1423-1437

Bode A, Gonzalez N, Rodriguez C, Varela M, Varela MM (2005) Seasonal variability of plankton blooms in the Ria 
de Ferrol (NW Spain). I. Nutrient concentrations and nitrogen uptake rates. Estuar Coast Shelf Sci 63:269-284

Boschker HTS, Middelburg JJ (2002) Stable isotopes and biomarkers in microbial ecology. FEMS Microbiol Ecol 40: 85-95

Boschker HTS, Kromkamp JC, Middelburg JJ (2005) Biomarker and carbon isotopic constraints on bacterial and algal community structure and functioning in a turbid, tidal estuary. Limnol Oceanogr 50:70-80

Bronk DA (2002) Dynamics of DON. In: Hansell DA, Carlson CA (eds) Biogeochemistry of marine dissolved organic matter. Academic Press, San Diego, CA, p 153-247

Bronk DA, Glibert PM (1993) Application of a N tracer method to the study of dissolved organic nitrogen uptake during spring and summer in Chesapeake Bay. Mar Biol 115:501-508

Bronk DA, Glibert PM, Malone TC, Banahan S, Sahlsten E (1998) Inorganic and organic nitrogen cycling in Chesapeake Bay: autotrophic versus heterotrophic processes and relationships to carbon fluxes. Aquat Microb Ecol 15:177-189

Bushaw KL, Zepp RG, Tarr MA, Schulz-Jander D and 5 others (1996) Photochemical release of biologically available nitrogen from aquatic dissolved organic matter. Nature 381:404-407

Dijkman NA, Kromkamp JC (in press) Phospholipid-derived fatty acids as chemotaxonomic markers for phytoplankton and application to derive phytoplankton composition in the Schelde estuary (Belgium and The Netherlands). Mar Ecol Prog Ser

Dortch Q (1990) The interaction between ammonium and nitrate uptake in phytoplankton. Mar Ecol Prog Ser 61: 183-201

Dugdale RC, Goering JJ (1967) Uptake of new and regenerated forms of nitrogen in primary productivity. Limnol Oceanogr 12:196-206

Dugdale RC, Wilkerson FP (1986) The use of ${ }^{15} \mathrm{~N}$ to measure nitrogen uptake in eutrophic oceans; experimental considerations. Limnol Oceanogr 31:673-689

Fan CL, Glibert PM (2005) Effects of light on nitrogen and carbon uptake during a Prorocentrum minimum bloom. Harmful Algae 4:629-641

Fan CL, Glibert PM, Burkholder JM (2003) Characterization of the affinity for nitrogen, uptake kinetics, and environmental relationships for Prorocentrum minimum in natural blooms and laboratory cultures. Harmful Algae 2:283-299

Fitznar HP, Lobbes JM, Kattner G (1999) Determination of enantiomeric amino acids with high-performance liquid chromatography and pre-column derivatisation with o-phthaldialdehyde and N-isobutyrylcysteine in seawater and fossil samples (mollusks). J Chromatogr A 832:123-132

Gazeau F, Gattuso JP, Middelburg JJ, Brion N, Schiettecatte LS, Frankignoulle M, Borges AV (2005) Planktonic and whole system metabolism in a nutrient-rich estuary (The Scheldt estuary). Estuaries 28:868-883

Goosen NK, Kromkamp J, Peene J, van Rijswijk P, van Breugel $P$ (1999) Bacterial and phytoplankton production in the maximum turbidity zone of three European estuaries: the Elbe, Westerschelde and Gironde. J Mar Syst 22:151-171

Heip C (1988) Biota and abiotic environment in the Westerschelde estuary. Hydrobiol Bull 22:31-34

Heip CHT, Herman PMJ (1995) Major biological processes in European tidal estuaries - a synthesis of the Jeep-92 Project. Hydrobiologia 311:1-7

Hoch MP, Kirchman DL (1995) Ammonium uptake by heterotrophic bacteria in the Delaware estuary and adjacent coastal waters. Limnol Oceanogr 40:886-897
Holmes RM, McClelland JW, Sigman DM, Fry B, Peterson BJ (1998) Measuring ${ }^{15} \mathrm{~N}-\mathrm{NH}_{4}{ }^{+}$in marine, estuarine and fresh waters: an adaptation of the ammonia diffusion method for samples with low ammonium concentrations. Mar Chem 60:235-243

Jørgensen NOG (2006) Uptake of urea by estuarine bacteria. Aquat Microb Ecol 42:227-242

Jørgensen NOG, Kroer N, Coffin RB, Yang XH, Lee C (1993) Dissolved free amino acids, combined amino acids, and DNA as sources of carbon and nitrogen to marinebacteria. Mar Ecol Prog Ser 98:135-148

Jørgensen NOG, Kroer N, Coffin RB, Hoch MP (1999) Relations between bacterial nitrogen metabolism and growth efficiency in an estuarine and an open-water ecosystem. Aquat Microb Ecol 18:247-261

Kanda J, Laws EA, Saino T, Hattori A (1987) An evaluation of isotope-dilution effect from conventional data sets of ${ }^{15} \mathrm{~N}$ uptake experiments. J Plankton Res 9:79-90

Kromkamp J, Peene J, van Rijswijk P, Sandee A, Goosen N (1995) Nutrients, light and primary production by phytoplankton and microphytobenthos in the eutrophic, turbid Westerschelde estuary (the Netherlands). Hydrobiologia 311:9-19

Linares F (2006) Effect of dissolved free amino acids (DFAA) on the biomass and production of microphytobenthic communities. J Exp Mar Biol Ecol 330:469-481

Lipschultz F, Wofsy SC, Fox LE (1986) Nitrogen-metabolism of the eutrophic Delaware River ecosystem. Limnol Oceanogr 31:701-716

McCarthy JJ, Taylor WR, Taft JL (1977) Nitrogenous nutrition of plankton in Chesapeake Bay. 1. Nutrient availability and phytoplankton preferences. Limnol Oceanogr 22: 996-1011

Middelboe M, Borch NH, Kirchman DL (1995) Bacterial utilization of dissolved free amino acids, dissolved combined amino acids and ammonium in the Delaware Bay estuary: effects of carbon and nitrogen limitation. Mar Ecol Prog Ser 128:109-120

Middelburg JJ, Nieuwenhuize J (2000a) Uptake of dissolved inorganic nitrogen in turbid, tidal estuaries. Mar Ecol Prog Ser 192:79-88

Middelburg JJ, Nieuwenhuize J (2000b) Nitrogen uptake by heterotrophic bacteria and phytoplankton in the nitrate-rich Thames estuary. Mar Ecol Prog Ser 203:13-21

Mobley HLT, Hausinger RP (1989) Microbial ureases — significance, regulation, and molecular characterization. Microbiol Rev 53:85-108

Mulholland MR, Glibert PM, Berg GM, van Heukelem L, Pantoja S, Lee C (1998) Extracellular amino acid oxidation by microplankton: a cross-ecosystem comparison. Aquat Microb Ecol 15:141-152

Mulholland MR, Gobler CJ, Lee C (2002) Peptide hydrolysis, amino acid oxidation, and nitrogen uptake in communities seasonally dominated by Aureococcus anophagefferens. Limnol Oceanogr 47:1094-1108

Mulholland MR, Lee C, Glibert PM (2003) Extracellular enzyme activity and uptake of carbon and nitrogen along an estuarine salinity and nutrient gradient. Mar Ecol Prog Ser 258:3-17

Mulholland MR, Boneillo G, Minor EC (2004) A comparison of $\mathrm{N}$ and $\mathrm{C}$ uptake during brown tide (Aureococcus anophagefferens) blooms from two coastal bays on the east coast of the USA. Harmful Algae 3:361-376

Nieuwenhuize J, Maas YEM, Middelburg JJ (1994) Rapid analysis of organic-carbon and nitrogen in particulate materials. Mar Chem 45:217-224 
Nilsson C, Sundbäck K (1996) Amino acid uptake in natural microphytobenthic assemblages studied by microautoradiography. Hydrobiologia 332:119-129

Oremland RS, Capone DG (1988) Use of specific inhibitors in biogeochemistry and microbial ecology. Adv Microb Ecol 10:285-383

Palenik B, Morel FMM (1990) Amino-acid utilization by marine-phytoplankton-a novel mechanism. Limnol Oceanogr 35:260-269

Pantoja S, Lee C (1994) Cell-surface oxidation of amino acids in seawater. Limnol Oceanogr 39:1718-1726

Petersen SO, Roslev P, Bol R (2004) Dynamics of a pasture soil microbial community after deposition of cattle urine amended with C-13 urea. Appl Environ Microbiol 70: 6363-6369

Phillips JC, Hurd CL (2003) Nitrogen ecophysiology of intertidal seaweeds from New Zealand: $\mathrm{N}$ uptake, storage and utilisation in relation to shore position and season. Mar Ecol Prog Ser 264:31-48

Price NM, Harrison PJ (1988) Uptake of urea-C and urea-N by the coastal marine diatom Thalassiosira pseudonana. Limnol Oceanogr 33:528-537

Rosenstock B, Simon M (2001) Sources and sinks of dissolved free amino acids and protein in a large and deep mesotrophic lake. Limnol Oceanogr 46:644-654

Seitzinger SP, Sanders RW, Styles R (2002) Bioavailability of DON from natural and anthropogenic sources to estuarine plankton. Limnol Oceanogr 47:353-366

Sigman DM, Altabet MA, Michener R, McCorkle DC, Fry B, Holmes RM (1997) Natural abundance-level measurement of the nitrogen isotopic composition of oceanic nitrate: an adaptation of the ammonia diffusion method. Mar Chem 57:227-242

Soetaert K, Middelburg JJ, Heip C, Meire P, Van Damme S, Maris T (2006) Long-term change in dissolved inorganic nutrients in the heterotrophic Scheldt estuary (Belgium, the Netherlands). Limnol Oceanogr 51:409-423

Editorial responsibility: Bess Ward, Princeton, New Jersey, USA
Stepanauskas R, Jørgensen NOG, Eigaard OR, Zvikas A, Tranvik LJ, Leonardson L (2002) Summer inputs of riverine nutrients to the Baltic Sea: bioavailability and eutrophication relevance. Ecol Monogr 72:579-597

Stolte W, Riegman R (1996) The relative preference index (RPI) for phytoplankton nitrogen use is only weakly related to physiological preference. J Plankton Res 18: 1041-1045

Tobias C, Giblin A, McClelland J, Tucker J, Peterson B (2003) Sediment DIN fluxes and preferential recycling of benthic microalgal nitrogen in a shallow macrotidal estuary. Mar Ecol Prog Ser 257:25-36

Veuger B, Middelburg JJ, Boschker HTS, Nieuwenhuize J, van Rijswijk P, Rochelle-Newall EJ, Navarro N (2004) Microbial uptake of dissolved organic and inorganic nitrogen in Randers Fjord. Estuar Coast Shelf Sci 61:507-515

Veuger B, Middelburg JJ, Boschker HTS, Houtekamer M (2005) Analysis of ${ }^{15} \mathrm{~N}$ incorporation into D-alanine: a new method for tracing nitrogen uptake by bacteria. Limnol Oceanogr Methods 3:230-240

Ward BB (2005) Temporal variability in nitrification rates and related biogeochemical factors in Monterey Bay, USA. Mar Ecol Prog Ser 292:97-109

Weston K, Jickells TD, Fernand L, Parker ER (2004) Nitrogen cycling in the southern North Sea: consequences for total nitrogen transport. Estuar Coast Shelf Sci 59:559-573

Wetsteyn L, Kromkamp J (1994) Turbidity, nutrients and phytoplankton primary production in the Oosterschelde (the Netherlands) before, during and after a large-scale coastal engineering project. Hydrobiologia 283:61-78

Wheeler PA, Kirchman DL (1986) Utilization of inorganic and organic nitrogen by bacteria in marine systems. Limnol Oceanogr 31:998-1009

Zehr JP, Ward BB (2002) Nitrogen cycling in the ocean: new perspectives on processes and paradigms. Appl Environ Microbiol 68:1015-1024

Submitted: December 15, 2005; Accepted: May 2, 2006 Proofs received from author(s): September 11, 2006 